\title{
Digital Apostleship: Evangelization in the New Agora
}

\author{
Justine Renus F. Galang ${ }^{1} \mathbb{D}$ and Willard Enrique R. Macaraan ${ }^{2, * \mathbb{D}}$ \\ 1 Department of Social Sciences, College of Arts and Sciences, Angeles University Foundation, \\ Pampanga 2009, Philippines; galang.justine@auf.edu.ph \\ 2 Theology and Religious Education Department, De La Salle University, Manila 1004, Philippines \\ * Correspondence: willard.macaraan@dlsu.edu.ph
}

check for

updates

Citation: Galang, Justine Renus F., and Willard Enrique R. Macaraan. 2021. Digital Apostleship:

Evangelization in the New Agora.

Religions 12: 92. https://doi.org/ $10.3390 /$ rel12020092

Academic Editor: Jason Bruner

Received: 7 January 2021

Accepted: 27 January 2021

Published: 29 January 2021

Publisher's Note: MDPI stays neutral with regard to jurisdictional claims in published maps and institutional affiliations.

Copyright: (c) 2021 by the authors. Licensee MDPI, Basel, Switzerland. This article is an open access article distributed under the terms and conditions of the Creative Commons Attribution (CC BY) license (https:// creativecommons.org/licenses/by/ $4.0 /)$.

\begin{abstract}
The digital space is understood not as a parallel and antithetical component of one's lived existentiality but a significant and substantial component of human existence that if ethically considered can be a platform for realizing religious identity, mission, and vocation. In this paper, social media platforms are argued as the new digital agoras that reflect the dynamics of the ancient Greek agoras. The nexus of interaction between the social media as the new agora and the Christian vocation and mission of evangelization and apostleship is the point of realized commitment among Christians to take part in the formation of a culture of synodality through an empowered and engaged presence in social media. Divided into two parts, the paper tackles social media platforms as the new agoras of the contemporary world and delves into a theological exploration of the digital apostleship in the new agoras with particular stress on the universality of the vocation and its potential contribution toward realizing the vision of a synodal Church.
\end{abstract}

Keywords: digital religion; cyberchurch; synodality; internet church; social media

\section{Introduction}

Benedict XVI (2013) in his message during the 47th World Communications Day noted the creation of a new agora with the evolution of the internet and digital social networks, particularly on how people dialogue, trade, and form relationships. In ancient Greece, agora is "mostly an open space designed for gathering and exchange" (Evangelidis 2014, p. 351). Earlier studies have already revealed that more than just a public place, the spatial organization of the Greek agora reflects social hierarchy, social networks, and relationships (Martin 1951; Jackson 1984 as cited by Evangelidis 2014, p. 336). It is within this ideational nuance of the Greek agora where Benedict XVI's reference to today's social networks as the "new" agora is located. As the ancient Greek agora was a place for people to hear civic announcements and discuss political issues, today's society has recreated it in digital space as people communicate, discuss, and trade in social media platforms like Facebook, Instagram, and Twitter. "Online religious communities also continued to rise in popularity, some focused around theological discussion or religious study, others offering prayer and support, and others seeking to provide common ground for affirming religious identity" (Campbell 2013, p. 6).

Social media as the new agora is unique in the sense that it engenders what Jenkins (2008) refers to as an "expression of participatory culture in which fans and other consumers are invited to actively participate in the creation and circulation of new content" (p. 331). Unlike in broadcasting platforms where the sender (broadcaster) unilaterally pushes the message to listeners as its recipients without any direct and immediate invitation to participate towards recrafting or recreating the original message other than perhaps rebroadcasting the same to others, the social media platforms empower an engaged audience, allowing the digital citizens to feel some degree of social connection with others as well as a conviction that their contributions matter. In the area of religious expressions and praxis, cyberspace has offered a medium for people to congregate in the name of faith and 
spirituality. The presence of religion in cyberspace gives birth to concepts and ideations of cyberchurch, internet church, online church, or digital church where religious groups facilitate their worship and prayer activities through the internet (Buckner 2010). For Campbell (2013), "Digital religion does not simply refer to religion as it is performed and articulated online, but points how digital media and spaces are shaping and being shaped by religious practice" (p. 1).

In these digital human communities, the Church ${ }^{1}$ constantly calls all Catholic faithful to diligently make present the Word of God. "Christianity is a mediated phenomenon, there is no aspect of Christianity that can exist except as it is being communicated" (Horsfield 2015, p. 8). The culture in Catholicism is very inclusive and the faith of the Catholic Church touches all aspects of life; thus, the Christian way of life must be practiced as well in this new reality-the digital reality (Paul VI 1974). Also, the Federation of Asian Bishops Conference (FABC) appeals for a "deeper discernment and appreciation of the modern means of communication, to seize all chances to employ mass and group media for evangelization and foster Christian values particularly among men and women in the media industry" (Federation of Asian Bishops' Conference (FABC) 2000, p. 5). FABC further reiterates that the fundamental reason for the Church's existence is Her communicative mission to proclaim the word of God. Even in the field of digital social media, the Church calls the Catholic faithful to proclaim Jesus, the Word made flesh who made His dwelling among humankind (Jn. 1:14). Accordingly, this invitation of the Church to bring and communicate Jesus on social media platforms is also embedded in the act of communication of God to humanity. The incarnation of God's Son Jesus is the high point of God's revelation (Federation of Asian Bishops' Conference (FABC) 2000, p. 3).

The nexus of interaction between the social media as the new agora and the Christian vocation and mission of evangelization and apostleship is the point of realized commitment among Christians to take part in the formation of a culture of synodality through an empowered and engaged presence in social media. The pontificate of Francis places emphasis on synodality. Synodality is focused on giving voice to the unheard by grounding the Church to the world outside Her ecclesial space. To be a synodal Church is to walk together- "The church has to live its life as a church, as a journey where the entire people are called to take part of this life. There are no bystanders, there is no audience in this journey" (McCormick 2018). This synodality must be democratic, though the collegial governance must remain important, in some other issues of the current world the voice of the bishops cannot be the only voice that is heard. This paper believes that the presence of the Church in social media opens up different avenues for the Church to walk together with all people. The social media platforms contribute towards "a participatory culture where the users, audiences, consumers and fans take part in the creation of culture and content" (Fuchs 2014, p. 52). Subscribers in various social media platforms do not just learn a culture alien to them, they too are creators and partakers of the establishment of brand-new cultures. This participatory culture propelled by these digital agoras would aid the Church in Her mission of synodality. The Church learns that beyond Her role as a sender of truth in social media and the world, She is also tasked to be one of the receivers of truths unveiled outside Her boundaries.

This paper is divided into two parts. First, it tackles social media platforms as the new agoras of the contemporary world. This part underlines how close these digital agoras are to the function of the ancient Greek agora, the heart of the city for dialogue, trade, and worship. Second, the paper delves into a theological exploration of the digital apostleship in the new agoras with particular stress on the universality of the vocation and its potential contribution toward realizing the vision of a synodal Church.

1 As part of its delimitation, the paper's reference to Church here is exclusively focused on the Roman Catholic Church without ignoring that post-Vatican II ecclesiology has since been more ecumenical and fraternal with non-Catholics and non-Christians. 


\section{Facebook as the New Agora}

Digital social communication is that which employs handheld gadgets such as smartphones and tablets and other electronic gadgets such as laptops and computers to construct shared platforms through which peoples and their communities discuss, share, and change their accounts' content (Kietzman et al. 2011, pp. 241-51). Primarily, these online platforms, today's agoras, are designed for people to communicate and express themselves in various ways.

Raphael's fresco School of Athens depicts the ancient Greek agora and all the great thinkers who passed through it. The Greek word "agora" means "open place of assembly" (Mark 2009). In modern Greek ideation, "agora" is understood as a "marketplace" but in ancient times, the Greek agora was more than its commercial function. Taking a cue from Pausanias, a Greek traveler, and geographer who is famous for his Description of Greece

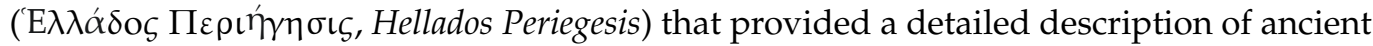
Greece during the second century $\mathrm{AD}$, an agora was always a venerable old square and not a commercial space (Robertson 1998, p. 286; Dickenson 2015, p. 739). Dominant in all of his documented observations is the multiple functions that are attributed to an agora in ancient times. Relative to the archaeological knowledge of a given site, an ancient agora can refer to "a commercial market, a square geared mainly toward government and administration, or a multipurpose public space combining various functions" (Dickenson 2015, p. 750). Over time, these open squares became the commercial heart of the city where merchants and craftsmen built their tents to sell their wares (Mark 2009). The agora eventually became the religious center for free-born citizens. It then had temples, altars, commemorative statues, and sometimes tombs of important personages (Jackson 1984). Simply, the agora is regarded to be the city's heart. It is the city's center for politics, commerce, and religion. People, such as traders and philosophers, did not only gather in the agora to buy and sell, converse, and worship-it was also a place to connect as they talked about things that concerned them: commerce, politics, current issues, and natural and supernatural phenomena.

In today's times, one cannot but notice the increasing evolution of digital space as the new agora. Whereas people in ancient times physically gathered in public squares to meet, discuss, interact, and engage on issues that matter, the social media platforms offered in digital space have provided venues for doing the same. In a social media platform, people assemble in a commonplace, governed by almost similar sets of expectations, ethos, and habitus, and just like any other human advancements, the digital agoras have also been subjected to malpractices, abuses, and all sorts of unethical practices. The ancient Greek agoras had also been venues where human slaves were sold and exchanged for profit. In digital platforms, a fair share of misinformation, fake news, and deceptions have also been perpetrated by some of its users (see Horsfield 2015, pp. 266-67).

Among the many social media platforms in the digital space, the paper limits its focus to the Facebook brand which is by far the most widely popular social media platform with 2.7 billion monthly active users (Clement 2020a). Facebook was founded in 2004 by Harvard students Mark Zuckerberg, Eduardo Saverin, Dustin Moskovitz, and Chris Hughes. It offers online social networking services. Early on, the company had a rough time. It all started as Facemash in 2003 at Harvard University, which was an online service for students mainly for connectivity and match-making. Due to accusations of unethically obtaining data and resources for its online services, Facemash was shut down after two days (Hall 2020). As of today, Facebook is free of charge. Users of Facebook can create their profiles, upload photos, join or start new groups or organizations. The site has many components such as Timeline, Status, and News Feed (Hall 2020).

As of October 2020, almost 4.66 billion people are active internet users (Clement $2020 \mathrm{~b})$. The internet has become a core pillar of modern communication. Outranking computers, mobile phones have now become the most important channel for internet access worldwide. The huge sales and demand for smartphones may be attributed to the popularity as well of the Facebook brand since most of its users access the social media 
platform almost exclusively via their mobile devices (Clement 2020a). Statistical evidence is herewith significant as it supports the fact that social media platforms, Facebook, in particular, have become the new agora for people to gather, discuss, buy, and worship. Even before the Covid-19 pandemic, various institutions have already utilized social media platforms to accomplish their missions and advance their reach. Han and Nasir (2016) even note how the recruitment for new members by terrorist organizations like the Islamic State (IS) has utilized the online platform (pp. 6-7).

\subsection{Civic and Social Engagement: The Facebook Pages}

Government offices and agencies have social media accounts (particularly Facebook). Social media is deemed an essential platform for government agencies (both national and local government units) to communicate and interact with their constituents. Consequently, people rely on these social media accounts to obtain information, directions, instructions, and guidelines particularly on concerns and issues related to their communities and civic obligations. Through this platform, the public is socio-politically engaged.

Facebook also contains features that may help businesses, enterprises, and organizations. Facebook Pages allows administrators to share stories and connect with people and this feature can be customized with stories, events, and more (Newberry 2020). International organizations utilize social media to advance their work. Many would probably go unnoticed without these social media platforms. In a study published by Twiplomacy, a site that provides a summary of a global study for world leaders with Twitter profiles, shows that all 97 multilateral international organizations and NGOs have their official accounts on the three main social networking sites: Twitter, Facebook, and Instagram (Lüfkens 2017). The study also proves that among the three, Facebook plays a key platform for these international organizations to engage their audience worldwide. The Facebook posts with the most interactions have been the three one-minute native videos posted by the World Economic Forum (WEF), the world's most engaging international organization on Facebook: Why being bored is good for children, Japanese Forest Bathing, and Why teenagers don't like getting up in the morning (Lüfkens 2017). The first video is the most popular post of any international organization with over 1 million interactions and more than 50 million views. The last two videos from WEF have garnered more than 32 million views. Meanwhile, the picture with the most interaction came from the World Bank (WB). World Banks' avatar gathered 721,111 interactions, and according to WB, this prompted 20,000 users to change their profile pictures and gave their organization a worldwide spotlight for their fight against poverty (Lüfkens 2017). UNICEF's picture of a young refugee with a caption "I'm a child, not a threat," holds the second spot for most engaging picture on Facebook. In addition, the UN Migration organization has attracted the most amazement with 6000 "wow" reactions (Lüfkens 2017). UN Migration's video on Facebook shows how Somalis abandoned their homes in search of food and water and how to make drinkable water with a coagulant. The availability and presence of international organizations, NGOs, government agencies, and offices on Facebook allow them to expand the extent of their advocacies and functions.

\subsection{Trade and Commerce: The Facebook Marketplace}

Even before the COVID-19 pandemic, business establishments have been present on many social media platforms. The abrupt growth of the internet impelled business firms to break free from the traditional way of selling their goods physically. Business owners today rely on social media platforms to promote and sell their brands. For consumers, digital marketing has also changed their buying and consumption dynamics and experience. Without even going out of the house, a product can be ordered and delivered through a couple of taps on the phone screen.

Business organizations use the internet or social media as an alternative vehicle to conduct their commercial transactions, though some started their businesses online. Since 2014, the global e-retail business has been growing. Amazon.com tops the list of 
global e-commerce retailers; JD.com, Suning Commerce Group, Apple, Walmart, Dell Technologies, Vipshop Holdings, Otto Group, Gome Electrical Appliances, and Macy's are also on the list (Angelovska 2019). Each of these websites curates its own unique online shopping experience. Facebook also has this online feature called the Facebook Marketplace. Launched in 2016, it allows Facebook users to browse a relevancy-sorted feed of things to buy from people who live nearby and quickly list one's stuff for sale (Constine 2016). Facebook provided a convenient place to search, buy, and sell materials with people in a particular community. The Marketplace makes it easy to find new things to love and find a new home for the things ready to dispose of ( $\mathrm{Ku}$ 2016). There are many reasons why people love online shopping. Aside from its usual convenience of hassle-free shopping, people can easily compare products and prices, choose different varieties from different stores, and be guaranteed customer privacy (Tran and Bar-Tur 2020).

\subsection{Worship: The Facebook Live}

Before the COVID-19 pandemic, religious institutions and groups have already tapped social media as their instruments in proclaiming the faith and communing with the congregation. The pandemic has further reinforced the functionality of social media for religious celebrations. While there are specific faith-based social media platforms, Facebook can also provide a venue to accommodate these religious and spiritual concerns. On 12 December 2012, a Twitter account was created for Pope Benedict XVI under the username @Pontifex, which is a Latin word that means bridge builder (Giangravé 2019). Currently, the @Pontifex Twitter account has about 18.7 million followers. Although managed by the papal office and not strictly a personal account, people have at least a sense of direct means of communication with the pope. In his account, the Roman Pontiff tweets his thoughts to the whole world.

The Philippine Catholic Church has also utilized the internet for evangelization and liturgical celebrations. Some have created their websites and even their own YouTube channels. One of the most revered and globally-recognized Filipino Church leaders, Cardinal Tagle, is also known for his enigmatic and charismatic social media presence. Among his many social media engagements, his regular segment The Word Exposed provides catechisms and biblical reflections for the subscribers and viewers.

On 6 April 2016, Facebook launched Facebook Live, its own live video streaming service. This feature offers raw and authentic broadcasting through its social platform or mobile app (Whitney 2020). It is free and available to all profiles and pages on the platform. Though this application is not created for religious purposes, religious institutions have employed this feature for real-time screening of their liturgical celebrations particularly the Holy Eucharist for Catholics. Fundamentally, this Facebook feature is for celebrities such as actors, musicians, and athletes to engage with their fans who can also leave comments (Mangalindan 2015). For the Church and other religions, this feature paved the way for the celebration of the worship services. Same as with the Catholic celebration of the mass on television, Facebook Live caters to those people who cannot physically attend the celebration. In this time of the pandemic, the Church temporarily dispenses the Catholic faithful from being physically present at the celebration of the Mass despite allowing limited entry of churchgoers in some areas. Instead, they encourage them to join in the celebration of Mass through Facebook Live. For now, as the governments give guidelines against public gatherings and social distancing, Catholic bishops responded to this government policy by deciding to celebrate the Holy Mass via live streaming video instead of opening the churches. The current administrator of the Archdiocese of Manila, Bishop Broderick Pabillo, admits that hearing Mass online is not the same as being physically present at the ceremony and regards it as a poor substitute (Macairan 2020). Moreover, Pabillo has published the Pastoral Instructions on How to Make the Most of the Online Mass as guidelines for attending online masses and liturgical celebrations. Though it is a poor alternative, online celebration of Mass is the safest response the Church can provide for the faithful given the strong directives and restrictions from the State. 
Social media has changed the dynamics of these human activities. Facebook Pages, Marketplace, and Live have together recreated a digital agora in modern times.

\section{The Digital Apostleship in Theological Lens}

"The interdisciplinary study of religion and the Internet highlights the growing recognition that new media has become embedded in our everyday lives and a common platform for spiritual engagement" (Campbell 2013, p. 10). The Church acknowledges that social media communication can be a vital service if used properly. In Vatican II's (1963) Inter Mirifica (IM) or the Decree on the Media of Social Communications, the council acknowledges that other than providing entertainment, social media enables the Church to guide the spread of the word of God (IM 2). Since there is an obvious appreciation of its potential and power, it too must be governed by the moral teachings the Church upholds (Zsupan-Jerome 2015, p. 21). The Church believes that same as with any product of the human mind, all means of social communications have ethical and moral aspects. Founded on God's self-communication to His creation, the Church has to keep the fact that Christianity is primarily a religious family of communication (Valdez 2015, p. 104).

IM may have been the most popular and well-known Church document on social communications due to magisterial authority as a conciliar document but predating it was an encyclical by Pope Pius XII-the Miranda Prorsus (On the Communication Fields: Movies, Television and Radio) in 1957. As social communications create broad discussions, $I M$ has focused less on how the Church can understand the means of social communication but more on how these instruments are of great use for the Church and all people of goodwill (Valdez 2015, p. 104). For the most part, the nature of the document exposes the moral and pastoral concerns of the Church, chiefly emphasizing instructions in ethically utilizing social communications in the Church and the society. The digital space of today is miles away from what it was in the 1960s, but the potential harm and abuses that social communications then could bring about necessitated a cautionary narrative behind this conciliar decree. The Council wanted to be proactive in offering guidance and wisdom for the proper utilization of digital communication to achieve both socio-economic progress and religio-spiritual salvation.

Faithful to Her mission to read the signs of the times, the Church continues to update Her pastoral guidance and teachings on social communications and media. While IM failed to draw inspiration from the major conciliar documents Lumen Gentium (1964) and Gaudium et Spes (GS, 1965) as it was promulgated before them in 1963, the pastoral instruction Communio et Progressio in 1971 had the benefit of gleaning from the emerging conciliar wisdom of the Church such as GS, Unitatis Redintegratio (1964), Dignitatis Humanae (1965), Ad Gentes Divinitus (1962-1965), Christus Dominus (1965), as well as IM. Twenty years after the promulgation of Communio et Progressio, the Church council promulgated Aetatis Novae in 1992. In 2002, the Pontifical Council for Social Communications came up with two documents: Ethics in Internet and The Church and Internet. Both are brief and stand on the shoulders of the social communication teachings offered in $I M$ and beyond. These two documents approach the communications medium of the internet from two related lenses: ethical and ecclesial-pastoral. To commemorate the 40th anniversary of IM in 2005, John Paul II issued an apostolic letter, The Rapid Development, to people and agencies who are responsible for communications. It delves into an affirmation of the power of social communication in the formation of a culture where the Church is tasked to incorporate the Word of God. This is the last apostolic letter on social communications. Inspired by promulgations from $I M$, the Church has been celebrating the Day of World Communications every 24 January in conjunction with the memorial of the patron of writers, St. Francis de Sales since 1967 until today. The papal messages delivered and shared during this annual celebration highlights reflections and pronouncements related to the dynamics of social communications and its impact on humanity in general.

What is noticeable in all these magisterial documents is Her eagerness and fervor to keep Herself up to date with the developments of social media communication and the 
internet. "How the religion should be mediated has been a recurring cause of conflict and contest throughout Christianity's history, in relation to not just modern technology but almost every dimension of communication practice" (Horsfield 2015, p. 287). Vatican II (1965) reiterates that the Church is to serve as a leaven and as a kind of soul for human society as it is renewed in Christ and transformed into God's family (GS 40). Through reading the changes and the challenges of the current times, the Church has been delivering brief and relevant messages on the consumption of social communication. In all these teachings of the Church, evangelization is the most important task of any Catholic faithful. The call for discipleship remains through the years. "The Christian missionary movement has been motivated, throughout its history, by the desire to mediate salvation to all" (Bosch 2011, p. 314). While significant changes abound in culture, lifeworlds, and even worldview, the vocation to be missionaries in this world has never been as urgent as now. The magisterial pronouncements remind the people that as the landscape has significantly changed to substantially include the digital narrative and discourse as normative to people's existential cosmology, and so is the extension of the praxis of apostleship into this new environment. Christians are called to be apostles in the digital space. To be digital apostles means to bring the narrative of Jesus and the teachings of the Church through and within the social media world. The Church exhorts Her people to acknowledge these platforms as new portals for evangelization. These teachings of the Church do not only spread the Word of God, but they also emphasize the authority of the Church in the world both real and digital. "Emerging practices of religious authorities facilitated by networked interactions may prompt updating of the understanding of authority in increasingly mediated environments" (Cheong 2013, p. 73).

To argue for stronger theological support to the ideation of digital apostleship in the new age, this section will further explore the universality of the call to apostleship and how the digital platform is an appropriate venue and expression towards the realization of the vision of a synodal Church, a vision that has recently dominated the papal pronouncements of Pope Francis. "It is precisely this path of synodality which God expects of the Church of the third millennium" (Francis 2015). By arguing that this call extends to all the faithful of the Church is an affirmation of the common baptism of Christians and the communal ecclesiology of Christianity. There is not one person who is worth more than any other. In the ideation of synodality, the image of a Church that listens reflects the dynamics of a community, dialogue, and gathering-characteristics one may find as well within the structure of an agora. Here, the paper would argue for its relevance as its attempt to explore the field of the digital agora and how it may contribute towards a clearer articulation of what it means to be a synodal Church.

\subsection{The Vocation of Apostleship in the New Age: The Faithful as Digital Apostles}

The environment may have significantly changed within the digital cosmos but the call to apostleship remains. The challenge shifts to becoming digital apostles where every Christian is sent to be a witness of Christ within the social media platform. More than merely listening and following, apostleship is primarily witnessing. An apostle is the one who is sent, but even before that, he knows Jesus. Apostles are sent not just to impart a message or communicate the teachings but more than ever, they are to be witnesses of the Risen Christ, inviting their listeners to encounter God's Word in person (Bohr 2009, p. 23).

Social media is greatly valued by the Church for its benefits towards humanity, particularly in aiding the Church in proclaiming the Gospel. Primarily, the mission of the Church to communicate is founded on God's self-communication toward mankind (IM 3). Through this new technology, the Church sees a new way of forming relationships. Most importantly, the new technology opens up new portals for the Church's evangelic mission (Benedict XVI 2013). As new portals of faith expression, evangelization performed in the digital space proclaims the same person Jesus Christ and His message of the Kingdom of God; the newness is not much in substance as it is in form and means. The Church reminds us that the Word of God still yearns for embodiment and incarnation in the physical realm. 
Evangelization entails not only the plain communication of faith since it also involves the peoples' witnessing of the faith through communicating their choices, inclinations, and verdicts that are based on the Gospel (Benedict XVI 2013). The Church sees social media as an important pastoral region in realizing the Kingdom of God concretized in the pursuit of social justice, peace, and solidarity. In his most recent encyclical Fratelli Tutti (FT), Francis (2020) ensures that prudence is key to ensuring that "present-day forms of communication are in fact guiding us to generous encounter with others, to honest pursuit of the whole truth, to service, to closeness to the underprivileged and to the promotion of the common good" (205). The vocation of apostleship is for all members of the Church. In Francis' (2013) apostolic exhortation, Evangelii Gaudium (EG), everyone has something to contribute as agents of evangelization regardless of one's theological education or formation (120).

Alongside this great opportunity for a renewed evangelization through social media is also a stern warning from Francis (2019) about the dangers and pitfalls it may bring about. In his post-synodal exhortation Christus Vivit $(C V)$, he outlines its limitations and deficiencies like cyberbullying, pornography, human trafficking, sexual exploitation, gambling, and the spread of fake news and false information that foment prejudice and hate. "Digital media can expose people to the risk of addiction, isolation and gradual loss of contact with concrete reality, blocking the development of authentic interpersonal relationships" ( $C V$ 88) and that the "Church and her pastors are not exempt from this phenomenon" (CV 89).

The urgency and necessity of a religious response to the vocation of digital apostleship must not be looked upon as only relevant in this time of pandemic when most social and work-related engagements have migrated to digital space. Admittedly reinforced more strongly by this pandemic, Benedict XVI (2013) clarifies that "the digital environment is not a parallel or purely virtual world, but is part of the daily experience of many people." It is increasingly important for the Good News to be proclaimed on the digital platform lest people may forget that it is an essential component of their religious existence.

\subsection{The Digital Apostleship as Essential Component in Realizing a Vision of a Synodal Church}

It was earlier reiterated that the digital space must not be purely treated as an antithesis to traditional public spaces of human encounters, communication, and dialogue for it is not a parallel universe from one's existential reality but an essential component of it. Since there are inherent challenges and limitations accorded to how social networks can provide authenticity and inclusivity, Benedict XVI (2013) also affirms its positive impact on evangelization particularly to youth ministry. The illusion that the virtual world is a world of its own that is wholly separated from one's actual "reality" hinders one to look at the promise of a renewed evangelization in digital space and the possibility of its complementary value to the overall well-being of one's religious faith, behavior, and mission. To acknowledge the weakness of digital connectivity to authentic interpersonal relationships is not to reduce its value as insignificant and therefore inconsequential to any ecclesial ministry and mission. On the contrary, the digital space is a complementary facet of one's existence-one that if ethically utilized and maximized can be a potential resource to building bridges, communion, and dialogue. Concerning youth ministry, for instance, Hunt (2020) affirms that it is futile to expect the youth to withdraw themselves of their digital participation as it is part of their existentiality and instead reinforces the need for digital accompaniment by adults "in accompanying young people as they navigate their faith living as digital people" (p. 7).

The main criticism hurled by Francis to digital platforms and connectivity is its assumption of human encounter and communion that is devoid of genuineness and authenticity. Francis (2020) is keen on its inadequacy; that it is "not enough to build bridges ... capable of uniting humanity" (FT 43). He adds that simply being connected does not equate to true encounters (Francis 2014). It is not a total rejection but a reservation of its inadequacy that unless digital connectivity transcends its virtual contact towards the actual 
encounter, one may fail to see the promise of digital apostleship towards evangelization and witnessing ( $C V$ 90).

Despite Francis' more critical stance against digital technologies when compared with his predecessors, he notes the extraordinary opportunities for dialogue, encounter, and exchange between persons" ( $C V$ 87). In the final document of the XV Ordinary General Assembly of the Synod of Bishops (2018), it makes explicit reference to the internet and social networks as a "public square" of interpersonal exchanges and communion (p. 22). Interestingly, this imagery of a public square resounds very intimately to the nuances and dynamics of the Greek agora which this paper argues is also reflective in the digital space as the new agora.

In pursuit of increased synodality in the Church, Francis envisions a listening Church that is more than just simply hearing; where listening is not one-directional but mutual "in which everyone (all the faithful people and the hierarchy) has something to learn" (Francis 2015). Synodality is an expression of a communal ecclesiology that affirms openness to the diversity of voices within the Church. For Colberg (2018), the degree and extent to which the inner voices within the Church are heard and listened to determine the ecumenical openness of the Church to also include the voices from other faith traditions. "... How we listen and who we listen to within our ecclesial community impacts who we listen to and what we hear outside of it" (p. 9). Synodality emerges from a desire to allow the voices of the faithful to be heard because after all, they have "instinctive ability to discern the new ways that the Lord is revealing to the Church" (Francis 2015). It is beyond exhibiting a posture of listening to the faithful "as it is also about becoming a 'consulting church' that actively seeks the input of the faithful regarding its teaching and modes of governance (Colberg 2018, p. 9).

By arguing for digital apostleship in the new agora of social media platforms, the paper affirms this magisterial direction provided within the cosmology of an ecclesiology of communion. The Church in digital space or the cyberchurch as referred to in other names is not a different parallel ecclesial structure but an extension or component that is significantly contributive towards the full realization of the Church as a whole. One cannot ignore the power of digital platforms particularly magnified by the increased virtual activities of people during this pandemic. Online masses have become normative and so are religious gatherings, bible studies, and even ecclesial meetings and discussions. Campbell and Vitullo (2019) believe that the Church can gain a lot in Her engagement in digital space and assert that Francis, while critical of digital technology, has interestingly become a popular religious figure because of "his succinct and evocative communication that is ideal and typical of digital culture" (p. 437). How social media has contributed to the popularity of Pope Francis (Narbona 2016) exposes that if utilized ethically with a positive disposition and perspective, the digital platforms can be powerful partners in the mission of evangelization.

\section{Conclusions}

The apostle Paul reminded the Christians of Corinth, "For what we preach is not ourselves, but Jesus Christ as Lord, with ourselves as your servants for Jesus' sake" (2 Cor. 4:5). At the very core of Christian apostleship is the call for servanthood. "The Son of Man came not to be served but to serve" (Mk. 10:45). Apostleship is foremost a privilege to serve and be a servant to others. In digital space, apostleship echoes the same spirit although within a complex set of dynamics that if ethically considered can be a powerful platform for evangelization and mission. The internet has been overcoming distance and time as barricades to communication. The internet's digital social media platforms have become the new agora where people discuss, trade, and worship. Magisterial tradition, at least in papal pronouncements of the post-Vatican II era has acknowledged the boon and bane of social media. What is strongly argued for in this paper is a positive articulation of digital platforms as venues for realizing the mission of all the faithful to be apostles in the digital world. The digital space is not a parallel antithetical component in one's existential reality 
but a complementary substantial component of one's existence, particularly in today's world.

The digital space is the new agora and the Church's explicit reference to it as a "public square" for dialogue, exchange, and communion strongly supports it. Much like the agora of ancient Greece, the social media platforms have been providing that space where people gather and commune at least virtually. In light of the Church's praxis of synodality, the paper has also explored how an appreciation of social media engagement can contribute towards the realization of this vision of a synodal Church —one that not only listens to all the faithful but also consults them.

As Jesus in Mt. 10:16 exhorts his apostles who he sent on a mission to be "like sheep into the midst of wolves;" he warns them about the realities that his apostles would encounter and for them to be able to handle and face this huge challenge, he further instructs them to "be wise as serpents and innocent as doves." Within the purview of digital apostleship, Christians are encouraged to be wise in choosing the battles they are to fight, the wisdom of the serpent teaches them to learn the boundaries of one's designated mission. Digital platforms, like any human institution, have their snares, traps, and deceptions, thus, digital apostles must be wise enough to know the areas to go into and dive. For Francis (2014), "we need tenderness ... The world of media also has to be concerned with humanity ..."

The Church sees these platforms as new portals for Her age-old mission of evangelizationof bringing Jesus to digital space. This is the new agora where Christians locate themselves not just to exchange trades and commodities but as venues for interaction, dialogue, and communion. The Church exhorts Her faithful to bring the Good News of faith and the mission of evangelization in this new agora. While aware of the dangers and the predatory tendencies of unregulated internet activities, Jesus' instruction is to be as wise as a serpent and as innocent as doves- to be cunning but pure.

Author Contributions: Conceptualization, J.R.F.G.; resources, J.R.F.G.; data curation, W.E.R.M.; formal analysis, W.E.R.M. and J.R.F.G.; writing—original draft preparation, J.R.F.G.; writing-review and editing, W.E.R.M.; supervision, W.E.R.M. All authors have read and agreed to the published version of the manuscript.

Funding: This research received no external funding.

Data Availability Statement: The data presented in this study are available on request from the authors.

Conflicts of Interest: The authors declare no conflict of interest.

\section{References}

Angelovska, Nina. 2019. Top 5 Online Retailers: 'Electronics And Media' Is The Star of E-Commerce Worldwide. Forbes, May 20. Available online: https:/ / www.forbes.com/sites/ninaangelovska/2019/05/20/top-5-online-retailers-electronics-and-mediais-the-star-of-e-commerce-worldwide/?sh=5ec6b1d81cd9 (accessed on 19 January 2021).

Benedict XVI. 2013. 47th World Communications Day: Social Networks: Portals of Truth and Faith. New Spaces for Evangelization. Vatican: Libreria Editrice Vaticana. Available online: http:/ / www.vatican.va/content/benedict-xvi/en/messages/communications / documents/hf_ben-xvi_mes_20130124_47th-world-communications-day.html (accessed on 27 December 2020).

Bohr, David. 2009. The Diocesan Priest: Consecrated and Sent. Collegevile: Liturgical Press. ISBN 978-081-463-278-9.

Bosch, David J. 2011. Transforming Mission: Paradigm Shifts in Theology of Mission, 2nd ed. New York: Orbis Books. ISBN 0-88344-744-4.

Buckner, Brandon. 2010. Redeeming the Internet. Collide Magazine 15: 24-25. Available online: https:/ / brandonbuckner.files.wordpress. com/2011/08/redeemingtheinternet.pdf (accessed on 27 December 2020).

Campbell, Heidi A. 2013. Digital Religion: Understanding Religious Practice in New Media Worlds. New York: Routledge Taylor\& Francis Group. ISBN 978-0-415-67610-6.

Campbell, Heidi A., and Alessandra Vitullo. 2019. Popes in Digital Era: Reflecting on the Rise of the Digital Papacy. Problemi Dell'Informazione 44: 419-42. [CrossRef]

Cheong, Pauline Hope. 2013. Authority. In Digital Religion: Understanding Religious Practice in New Media Worlds. Edited by Heidi A. Campbell. New York City: Routledge Taylor\& Francis. ISBN 978-0-415-67610-6. 
Clement, J. 2020a. Facebook: Number of Monthly Active Users Worldwide 2008-2020. Statista, January 27. Available online: https://www.statista.com/statistics/264810/number-of-monthly-active-facebook-users-worldwide/ (accessed on 16 January 2021).

Clement, J. 2020b. Worldwide Digital Population as of October 2020. Statista, January 27. Available online: https://www.statista.com/ statistics/617136/digital-population-worldwide/ (accessed on 16 January 2021).

Colberg, Kristin. 2018. Ecumenical Ecclesiology in its New Contexts: Considering the Transformed Relationship between Roman Catholic Ecclesiology and Ecumenism. Religions 9: 291. [CrossRef]

Constine, Josh. 2016. Facebook Launches Marketplace, a Friendlier Craigslist. TechCrunch, October 3. Available online: https: / / techcrunch.com/2016/10/03/facebook-marketplace-2/ (accessed on 28 December 2020).

Dickenson, Christopher P. 2015. Pausanias and the 'Archaic Agora' at Athens. Hesperia: The Journal of the American School of Classical Studies at Athens 84: 723-70. [CrossRef]

Evangelidis, Vasilis. 2014. Agoras and Fora: Developments in the Central Public Space of the Cities of Greece during the Roman Period. The Annual of the British School of Athens 109: 335-56. [CrossRef]

Federation of Asian Bishops' Conference (FABC). 2000. Church and Social Communication in Asia: Basics for Social Communication in Asia" No. 92a. Available online: http:/ / www.fabc.org/fabc\%20papers/fabc_paper_92a.pdf (accessed on 27 December 2020).

Francis. 2013. Evangelii Gaudium. Vatican: Libreria Editrice Vaticana. Available online: http://www.vatican.va/content/francesco/en/ apost_exhortations/documents/papa-francesco_esortazione-ap_20131124_evangelii-gaudium.html (accessed on 17 January 2021).

Francis. 2014. XLVIII World Communications Day, 2014-Communications at the Service of an Authentic Culture of Encounter. Vatican: Libreria Editrice Vaticana. Available online: http:/ /www.vatican.va/content/francesco/en/messages/communications/documents / papa-francesco_20140124_messaggio-comunicazioni-sociali.html (accessed on 18 January 2021).

Francis. 2015. Ceremony Commemorating the 50th Anniversary of the Institution of the Synod of Bishops: Address of His Holiness Pope Francis. Vatican: Libreria Editrice Vaticana. Available online: http:/ / www.vatican.va/content/francesco/en/speeches/2015/october/ documents/papa-francesco_20151017_50-anniversario-sinodo.html (accessed on 19 January 2021).

Francis. 2019. Christus Vivit. Vatican: Libreria Editrice Vaticana. Available online: http:/ /www.vatican.va/content/francesco/en/ apost_exhortations/documents/papa-francesco_esortazione-ap_20190325_christus-vivit.html (accessed on 17 January 2021).

Francis. 2020. Fratelli Tutti. Vatican: Libreria Editrice Vaticana. Available online: http://www.vatican.va/content/francesco/en/ encyclicals/documents / papa-francesco_20201003_enciclica-fratelli-tutti.html (accessed on 17 January 2021).

Fuchs, Christian. 2014. Social Media: A Critical Introduction. Media. London: SAGE Publications Ltd. ISBN 978-1-4462-5730-2.

Giangravé, Claire. 2019. Seven Years in, Pope's Twitter Account Garners Success, Criticism and Comic Mishaps. Religion News Service. December 12. Available online: https: / religionnews.com/2019/12/12/seven-years-in-popes-twitter-account-garners-successcriticism-and-comic-mishaps / (accessed on 29 December 2020).

Hall, Mark. 2020. Facebook. Encyclopaedia Britannica. Available online: https://www.britannica.com/topic/Facebook (accessed on 30 December 2020).

Han, Sam, and Kamaludeen Mohamed Nasir. 2016. Digital Culture and Religion in Asia. New York: Routledge. ISBN 9781138476196.

Horsfield, Peter. 2015. From Jesus to the Internet: A History of Christianity and Media. West Sussex: Wiley Blackwell. ISBN 978-1118447383.

Hunt, Jodi. 2020. And There was Zoom: A Catholic Theological Examination on the Development of Digital Youth Ministry. Religions 11: 565. [CrossRef]

Jackson, John Brinckerhoff. 1984. Discovering the Vernacular Landscape. London: Yale University Press. ISBN 978-030-003-581-0.

Jenkins, Henry. 2008. Convergence Culture. New York: New York University Press. ISBN 978-081-474-295-2.

Kietzman, Jan H., Kristopher Hermkens, Ian P. McCarthy, and Bruno S. Silvestre. 2011. Social Media? Get Serious! Understanding the Functional Building Blocks of Social Media. Business Horizons 54: 241-51. [CrossRef]

Ku, Mary. 2016. Introducing Marketplace: Buy and Sell With Your Local Community_About Facebook. Facebook, October 3. Available online: https:/ / about.fb.com/news/2016/10/introducing-marketplace-buy-and-sell-with-your-local-community/ (accessed on 28 December 2020).

Lüfkens, Matthias. 2017. International Organisations on Social Media 2017. Twiplomacy, November 29. Available online: https: / / twiplomacy.com/blog/international-organisations-on-social-media-2017/ (accessed on 19 January 2021).

Macairan, Evelyn. 2020. Online Masses Not Enough, Bishop Says. Philstar Global, June 15. Available online: https: / www.philstar. com/headlines/2020/06/15/2020955/online-masses-not-enough-bishop-says (accessed on 28 December 2020).

Mangalindan, J. P. 2015. Facebook Launches Live Streaming, but Only for Famous People. Mashable, August 5. Available online: https:/ / mashable.com/2015/08/05/facebook-live-streaming-celebrities/ (accessed on 29 December 2020).

Mark, Joshua J. 2009. Agora. Ancient History Encyclopedia. Available online: https:/ / www.ancient.eu/agora/ (accessed on 30 December 2020).

Martin, Roland. 1951. Recherches sur l'Agora grecque, Etudes d'histoire et d'architecture urbaines. Bibliotheque Des Ecoles Francaises D'Athenes et de Rome. Paris: Editions de Boccard.

McCormick, Bill. 2018. Greater Inclusion at the Synod Could Complicate Collegiality among Bishops. America Magazine, October 26. Available online: https:/ /www.americamagazine.org/faith/2018/10/26/greater-inclusion-synod-could-complicate-collegialityamong-bishops (accessed on 29 December 2020).

Narbona, Juan. 2016. Digital Leadership, Twitter and Pope Francis. Church Communication and Culture 1: 90-109. [CrossRef] 
Newberry, Christina. 2020. Facebook Marketing in 2020: How to Use Facebook for Business. Hootsuite. Available online: https: // blog.hootsuite.com/facebook-marketing-tips/ (accessed on 30 December 2020).

Paul VI. 1974. Message of the Holy Father for the World Social Communications Day: Social Communications and Evangelization in Today's World. Vatican: Libreria Editrice Vaticana. Available online: http:/ /w2.vatican.va/content/paul-vi/en/messages/communications / documents/hf_p-vi_mes_19740516_viii-com-day.html (accessed on 29 December 2020).

Robertson, Noel. 1998. The City Center of Archaic Athens. Hesperia 67: 283-302. [CrossRef]

Tran, Tony, and Yael Bar-Tur. 2020. Social Media in Government: Benefits, Challenges, and How It's Used. Hootsuite. Available online: https:/ / blog.hootsuite.com/social-media-government/ (accessed on 29 December 2020).

Valdez, Earl A. P. 2015. Sketching a Christian Social Media Ethics through Inter Mirifica and the Church's Teaching on Social Communications. Pamisulu: An Interdisciplinary Journal of Theology and Philosophy 3: 104-18.

Vatican II. 1963. Inter Mirifica. Vatican: Libreria Editrice Vaticana. Available online: https:/ /www.vatican.va/archive/hist_councils/ii_ vatican_council/documents/vat-ii_decree_19631204_inter-mirifica_en.html (accessed on 30 December 2020).

Vatican II. 1965. Gaudium et Spes. Vatican: Libreria Editrice Vaticana. Available online: http://www.vatican.va/archive/hist_councils/ ii_vatican_council/documents/vat-ii_const_19651207_gaudium-et-spes_en.html (accessed on 30 December 2020).

Whitney, Margot. 2020. The Ridiculously Awesome Guide to Facebook Live. Wordstream, June 1. Available online: https://www. wordstream.com/blog/ws/2017/07/31/facebook-live-guide (accessed on 28 December 2020).

XV Ordinary General Assembly of the Synod of Bishops. 2018. Final Document of the Synod of Bishops on Young People, Faith and Vocation Discernment. Vatican: General Secretariat of the Synod of Bishops. Available online: http://www.synod.va/content/synod2018/ en/fede-discernimento-vocazione/final-document-of-the-synod-of-bishops-on-young-people--faith-an.html (accessed on 18 January 2021).

Zsupan-Jerome, Daniella. 2015. Connected toward Communion: The Church and Social Communication in the Digital Age. Collegeville: Liturgical Press. ISBN 978-081-468-220-3. 